Jurnal Keperawatan Silampari

Volume 5, Nomor 1, Desember 2021

e-ISSN: 2581-1975

p-ISSN: 2597-7482

DOI: https://doi.org/10.31539/jks.v5i1.2906

\title{
FAKTOR-FAKTOR YANG BERHUBUNGAN DENGAN SELF CARE MANAGEMENT PADA PASIEN HIPERTENSI
}

\author{
Fernalia $^{1}$, Buyung Keraman ${ }^{2}$, Rahmad Satrio Putra ${ }^{3}$ \\ Sekolah Tinggi Ilmu Kesehatan Tri Mandiri Sakti Bengkulu ${ }^{1,2,3}$ \\ lia_fernalia@yahoo.com ${ }^{1}$
}

\begin{abstract}
ABSTRAK
Penelitian ini bertujuan untuk mengetahui faktor-faktor yang berhubungan dengan self care management pada pasien hipertensi di Pukesmas Kabawetan. Metode yang digunakan dalam penelitian ini adalah penelitian kuantatif dengan desain survey analitik yang menggunakan rancangan penelitian cross sectional. Hasil penelitian menunjukkan bahwa dari 42 orang pasien hipertensi mayoritas responden dengan self care management baik yaitu sebanyak 24 orang $(57,1 \%), 14$ orang $(33,3 \%)$ dengan pengetahuan kurang, 22 orang $(52,4 \%)$ dengan nilai individu yang baik, dan 25 orang $(59,5 \%)$ dengan efikasi diri yang baik. Hasil analisis bivariat menunjukkan bahwa nilai $\mathrm{p}<0,05$. Simpulan, ada hubungan yang signifikan antara pengetahuan, nilai individu dan efikasi diri dengan self care management pasien hipertensi di Pukesmas Kabawetan.
\end{abstract}

Kata Kunci : Efikasi Diri, Nilai, Pengetahuan, Self Care Management

\section{ABSTRACT}

This study aims to determine the factors associated with self-care management in hypertensive patients at the Kabawetan Public Health Center. The method used in this study is a quantitative study with an analytical survey design using a cross-sectional research design. The results showed that from 42 hypertensive patients, the majority of respondents with good self-care management were 24 people $(57.1 \%), 14$ people (33.3\%) with poor knowledge, 22 people (52.4\%) with individual scores. Good, and 25 people (59.5\%) with good self-efficacy. The results of the bivariate analysis showed that the p-value <0.05. In conclusion, there is a significant relationship between knowledge, individual values, and self-efficacy with the self-care management of hypertensive patients at the Kabawetan Public Health Center.

Keywords: Self-Efficacy, Values, Knowledge, Self Care Management

\section{PENDAHULUAN}

Penyakit hipertensi menjadi permasalahan kesehatan utama di Negara maju dan Negara berkembang, hipertensi merupakan penyakit yang tidak menular dan merupakan penyebab kematian nomor satu secara global (Mahfud et al., 2019). Hipertensi adalah suatu keadaan dimana tekanan darah menjadi naik karena gangguan pada pembuluh darah yang mengakibatkan suplai oksigen dan nutrisi terganggu sampai ke jaringan tubuh yang membutuhkannya (Puspita et al., 2019). Menurut WHO (World Health Organization) Hipertensi adalah tekanan darah sistolik yang sama dengan atau di atas 
$140 \mathrm{mmHg}$ dan atau tekanan darah diastolik sama dengan atau di atas $90 \mathrm{mmHg}$ (Sakinah et al., 2020; Harsismanto et al., 2020).

Berdasarkan data dari WHO tahun 2019 diketahui bahwa jumlah orang dewasa dengan hipertensi meningkat dari 594 juta pada tahun 1975 menjadi 1,13 miliar pada tahun 2015. Penyakit ini berkembang dengan pesat di negara-negara berpenghasilan rendah dan menengah. Peningkatan ini terutama disebabkan oleh peningkatan faktor risiko hipertensi pada populasi tersebut. Prevalensi hipertensi tertinggi di Afrika mencapai $(27 \%)$ sedangkan prevalensi hipertensi terendah di Amerika sebesar (18\%) (WHO, 2019).

Estimasi jumlah kasus hipertensi di Indonesia sebesar 63.309.620 orang, sedangkan angka kematian di Indonesia akibat hipertensi sebesar 427.218 kematian. Hipertensi terjadi pada kelompok umur 31-44 tahun (31,6\%), umur 45-54 tahun $(45,3 \%)$, umur 55-64 tahun (55,2\%). Hipertensi disebut sebagai the silent killer karena sering tanpa keluhan, sehingga penderita tidak mengetahui dirinya menyandang hipertensi dan baru diketahui setelah terjadi komplikasi (Andri et al., 2021; Sihotang et al., 2020).

Hipertensi dapat dipicu oleh faktor yang tidak dapat dikontrol dan faktor yang tidak dapat dikontrol. Faktor yang tidak dapat dikontrol diantaranya seperti keturunan, jenis kelamin, dan usia. Sedangkan faktor yang dapat dikontrol diantaranya seperti obesitas, diet hipertensi, stres, aktivitas fisik, dan merokok (Puspita et al., 2019). Urbanisasi yang cepat, gaya hidup, junkfood, dan stress juga merupakan faktor risiko yang bertanggung jawab untuk terjadinya peningkatan prevalensi hipertensi (Sartika et al., 2020; Andri et al., 2018). Hipertensi dapat dicegah dengan mengendalikan perilaku berisiko seperti merokok, diet yang tidak sehat seperti kurang konsumsi sayur dan buah serta konsumsi gula, garam dan lemak berlebih, obesitas, kurang aktifitas fisik, konsumsi alkohol berlebihan dan stress dengan self care management (Sihotang et al., 2020).

Hipertensi merupakan penyakit kronik, oleh sebab itu pasien harus bertanggung jawab dalam melakukan pengelolaan diri sendiri (self management) baik untuk menurunkan gejala maupun menurunkan risiko komplikasi (Shahaj et al., 2019). Self management adalah prosedur pada individu untuk mengatur prilakunya sendiri. Self management dapat mendorong pasien menggunakan sumber daya yang ada untuk mengelola penyakit yang dialaminya (Lestari \& Isnaini, 2018). Self management pada penderita hipertensi meliputi kontrol tekanan darah dan pengobatan, perbaiki gaya hidup dan pencegahan terhadap komplikasi yang akan terjadi (Sakinah et al., 2020).

Self care merupakan suatu kegiatan yang dibuat dan dilakukan oleh individu itu sendiri untuk mempertahankan kehidupan yang sejahtera baik itu dalam keadaan sehat ataupun sakit. Self Care pada pasien hipertensi merupakan salah satu bentuk usaha positif klien untuk mengoptimalkan kesehatan dari klien, mengontrol dan memanagement tanda dan gejala yang muncul, mencegah terjadinya komplikasi dan meminimalkan gangguan yang timbul pada fungsi tubuh (Winata et al., 2018).

Kegiatan dalam self care management hipertensi meliputi penggunaan obat anti hipertensi secara benar, kegiatan untuk memantau tekanan darah dan gejala yang muncul terkait penyakit hipertensi, pengaturan diet yaitu diet yang sesuai untuk penatalaksaanaan hipertensi, melakukan olahraga sesuai petunjuk untuk menurunkan tekanan darah dan kegiatan untuk mencegah komplikasi yang berhubungan dengan hipertensi (Sihotang et al., 2020). 
Terdapat beberapa faktor yang mempengaruhi self management pada penderita hipertensi diantaranya adalah pengetahuan, tingkat pendidikan, dukungan sosial, keyakinan diri (self efikasi) dan lama menderita penyakit hipertensi. Pengetahuan yang dimiliki oleh pasien akan meningkatkan rasa percaya diri dan menumbuhkan keyakinan pasien terhadap efektivitas pengobatan hipertensi. Oleh karena itu, pemahaman terhadap penyakit harus dilakukan secara menyeluruh, baik faktor risikonya, diagnosanya, penanganannya maupun komplikasinya. Self management pada penderita hipertensi yang dilakukan secara efektif bermanfaat untuk meningkatkan kepuasan pasien dalam menjalani hidup, menurunkan biaya perawatan, meningkatkan rasa percaya diri dan kemandirian pasien, serta meningkatkan kualitas hidup pasien (Sakinah et al., 2020).

Self management hipertensi sangat dibutuhkan agar pasien tidak mengalami penurunan kesehatan dikarenakan penyakit sering berulang. Self management mengarah pada tindakan untuk mempertahankan perilaku yang efektif meliputi penggunaan obat yang diresepkan, mengikuti diet dan olahraga, pamantauan secara mandiri dan koping emosional dengan penyakit yang diderita (Fernalia et al., 2019).

Fenomena yang ada di daerah Kecamatan Kepahiang Provinsi Bengkulu pada pasien hipertensi, secara umum pasien hipertensi lebih mengutamakan upaya farmakologi dan kurang diimbangi dengan upaya non farmakologis. Upaya non farmakologis yaitu dengan memodifikasi gaya hidup yang meliputi diet, pengendalian berat badan dan aktifitas fisik dalam self care management hipertensi yang dilakukan. Kunjungan pasien hipertensi ke pelayanan kesehatan secara umum disebabkan karena terjadinya gejala hipertensi yang dianggap sebagai ganguan oleh pasien. Dari fenomena tersebut maka dapat diasumsikan bahwa pelaksanaan self care management pada pasien hipertensi di Pukesmas Kabawetan Kabupaten Kepahiang masih kurang efektif dibuktikan secara umum pasien hipertensi hanya menekankan pada salah satu aspek dari self care management, sedangkan kegiatan yang lain seperti olahraga, pengaturan diet, pemantau kesehatan mandiri dan koping emosional kurang mendapat perhatian.

Penelitian ini mempelajari tentang faktor-faktor yang berhubungan dengan self care management hipertensi, berbeda dengan penelitian sebelumnya yang meneliti tentang self care management pada heart failure disease. Pada penelitian ini akan dibahas tentang hubungan antara pengetahuan dengan self care management, hubungan antara nilai individu dengan self care management, dan hubungan antara efikasi diri dengan self care management pada pasien hipertensi.

\section{METODE PENELITIAN}

Penelitian ini merupakan penelitian kuantatif dengan desain survey analitik yang menggunakan rancangan penelitian cross sectional dimana variable independen (pengetahuan, nilai, efikasi diri) dan variabel dependen (self care management) di ukur secara langsung dalam waktu yang bersamaan. Populasi dalam penelitian ini adalah seluruh pasien hipertensi di wilayah kerja Puskesmas Kabawetan yang berjumlah 198 responden dengan pengambilann sampel menggunakan teknik accidental sampling sehingga didapat sampel sebanyak 42 responden.

Penelitian ini telah dilakukan di wilayah kerja Puskesmas Kabawetan Kepahiang pada bulan Agustus 2018. Penelitian ini menggunakan data primer yang diperoleh dari wawancara dan penyebaran kuesioner pasien hipertensi di wilayah kerja Puskesmas Kabawetan. Kuesioner pengetahuan yang digunakan terdiri 10 butir soal dengan plihan jawaban benar atau salah. Kuesoner nilai terdiri dari 7 pertanyaan dengan menggunakan pilihan jawaban Sangat setuju (4), Setuju (3), Kurang setuju (2) dan Sangat tidak setuju 
(1). Pada kuesioner efikasi diri terdiri dari 10 butir pertanyaan dengan pilihan jawaban Mampu Melakukan (3), Kurang Mampu (2) dan Tidak Mampu (1). Pada kuesioner self care management terdiri dari 10 pertanyaan dengan pilihan jawaban Selalu (4), Sering (3), Jarang (2) dan Tidak Pernah (1). Data yang didapatkan selanjutnya dimasukkan ke dalam lembar isian.

Analisis pada penelitian ini terdiri dari beberapa tahap. Tahap pertama analisis penelitian menggunakan analisis univariat yang bertujuan untuk memperoleh gambaran tentang variable independen (pengetahuan, nilai, efikasi diri) dan variabel dependen (self care management) di wilayah kerja Puskesmas Kabawetan Kepahiang. Selanjutnya dilakukan analisis bivariat yang bertujuan untuk melihat hubungan antara variable independen (pengetahuan, nilai, efikasi diri) dan variabel dependen (self care management) dengan menggunakan analisis Chi-Square $\left(\chi^{2}\right)$.

\section{HASIL PENELITIAN}

Tabel. 1

Gambaran Self Care Management Pasien Hipertensi

\begin{tabular}{ccc}
\hline $\begin{array}{c}\text { Self Care Management Pasien } \\
\text { Hipertensi }\end{array}$ & Frekuensi & Presentase (\%) \\
\hline Kurang & 18 & 42,9 \\
Baik & 24 & 57,1 \\
\hline Total & 42 & 100,0 \\
\hline
\end{tabular}

Berdasarkan tabel 1 tampak bahwa dari 42 orang pasien hipertensi mayoritas responden dengan self care management baik yaitu sebanyak 24 orang $(57,1 \%)$.

Tabel. 2

Gambaran Pengetahuan Pasien Hipertensi

\begin{tabular}{ccc}
\hline Pengetahuan & Frekuensi & Presentase (\%) \\
\hline Kurang & 14 & 33.3 \\
Cukup & 13 & 31.0 \\
Baik & 15 & 35.7 \\
\hline Total & 42 & 100,0 \\
\hline
\end{tabular}

Berdasarkan tabel 2 tampak bahwa dari 42 orang pasien hipertensi terdapat 15 orang $(35,7 \%)$ dengan pengetahuan baik.

Tabel. 3

Gambaran Nilai Individu Pasien Hipertensi

\begin{tabular}{ccc}
\hline Nilai & Frekuensi & Presentase (\%) \\
\hline Kurang & 20 & 47,6 \\
Baik & 22 & 52,4 \\
\hline Total & 42 & 100,0 \\
\hline
\end{tabular}

Berdasarkan tabel 3, tampak bahwa dari 42 orang pasien hipertensi terdapat 22 orang $(52,4 \%)$ dengan nilai individu yang baik. 
Tabel 4

Gambaran Efikasi Diri Pasien Hipertensi

\begin{tabular}{ccc}
\hline Efikasi Diri & Frekuensi & Presentase (\%) \\
\hline Kurang & 17 & 40.5 \\
Baik & 25 & 59.5 \\
\hline Total & 42 & 100.0 \\
\hline
\end{tabular}

Berdasarkan tabel 4 tampak bahwa dari 42 orang pasien hipertensi terdapat 25 orang $(59,5 \%)$ dengan efikasi diri yang baik.

Tabel. 5

Hubungan Pengetahuan dengan Self Care Management pada Pasien Hipertensi

\begin{tabular}{cccccccc}
\hline \multirow{2}{*}{ Pengetahuan } & \multicolumn{2}{c}{ Self Care Management } & Total & \multirow{2}{*}{$\chi^{2}$} & $\mathrm{p}$ & $\mathrm{C}$ \\
\cline { 2 - 4 } & Kurang & Baik & & & & & \\
\hline Kurang & 10 & 4 & 14 & & & \\
cukup & 6 & 7 & 13 & 10,063 & 0,007 & 0,440 \\
Baik & 2 & 13 & 15 & & & \\
\hline Total & 18 & 24 & 42 & & & \\
\hline
\end{tabular}

Berdasarkan table 5, tabulasi silang antara pengetahuan dengan self care management pasien hipertensi, didapatkan dari 14 orang dengan pengetahuan kurang terdapat 10 orang dengan self care management kurang baik dan 4 orang dengan self care management baik. Dari 13 orang dengan pengetahuan cukup terdapat 6 orang dengan self care management kurang baik dan 7 orang dengan self care management baik. Dari 15 orang dengan pengetahuan baik terdapat 2 orang dengan self care management kurang baik dan 13 orang dengan self care management baik.

Hasil uji statistic Chi-Square (Pearson Chi-Square) didapat nilai $\chi 2=10,063$ dengan $\mathrm{p}=0,007<\alpha(0,05)$ berarti signifikan, maka Ho ditolak Ha diterima. Jadi terdapat hubungan yang signifikan antara pengetahuan dengan self care management pasien hipertensi di Pukesmas Kabawetan.

Tabel. 6

Hubungan Nilai Individu dengan Self Care Management pada Pasien Hipertensi

\begin{tabular}{|c|c|c|c|c|c|c|}
\hline \multirow{2}{*}{ Nilai } & \multicolumn{2}{|c|}{ Self Care Management } & \multirow{2}{*}{ Total } & \multirow{2}{*}{$\chi^{2}$} & \multirow{2}{*}{$\mathrm{p}$} & \multirow{2}{*}{$\mathrm{C}$} \\
\hline & Kurang & Baik & & & & \\
\hline Kurang & 13 & 7 & 20 & \multirow{3}{*}{6,016} & \multirow{3}{*}{0,014} & \multirow{3}{*}{0,392} \\
\hline Baik & 5 & 17 & 22 & & & \\
\hline Total & 18 & 24 & 42 & & & \\
\hline
\end{tabular}

Berdasarkan tabel 6 tabulasi silang antara pengetahuan dengan self care management pasien hipertensi, didapatkan dari 20 orang dengan nilai individu kurang baik terdapat 13 orang dengan self care management kurang baik dan 7 orang dengan self care management baik. Dari 22 orang dengan nilai individu baik terdapat 5 orang dengan self care management kurang baik dan 17 orang dengan self care management baik 
Hasil uji statistic Chi-Square (Continuity Correction) didapat nilai $\chi 2=6,016$ dengan $\mathrm{p}=0,014<\alpha(0,05)$ berarti terdapat hubungan yang signifikan antara nilai individu dengan self care management pasien hipertensi di Pukesmas Kabawetan.

Tabel. 7

Hubungan Efikasi Diri dengan Self Care Management pada Pasien Hipertensi

\begin{tabular}{cccccccc}
\hline \multirow{2}{*}{ Efikasi Diri } & \multicolumn{2}{c}{ Self Care Management } & \multirow{2}{*}{ Total } & \multirow{2}{*}{$\chi^{2}$} & $\mathrm{p}$ & $\mathrm{C}$ \\
\cline { 2 - 4 } & Kurang & Baik & & & & & \\
\hline Kurang & 12 & 5 & 17 & & \multirow{2}{*}{7,167} & 0,007 & 0,419 \\
Baik & 6 & 19 & 25 & & & \\
\hline Total & 18 & 24 & 42 & & & \\
\hline
\end{tabular}

Berdasarkan tabel 7, tabulasi silang antara pengetahuan dengan self care management pasien hipertensi, didapatkan dari 17 orang dengan efikasi diri kurang baik terdapat 12 orang dengan self care management kurang baik dan 5 orang dengan self care management baik. Dari 25 orang dengan efikasi diri baik terdapat 6 orang dengan self care management kurang baik dan 19 orang dengan self care management baik

Hasil uji statistic Chi-Square (Continuity Correction) didapat nilai $\chi^{2}=7,167$ dengan $\mathrm{p}=0,007<\alpha(0,05)$ berarti signifikan, maka terdapat hubungan yang signifikan antara efikasi diri dengan self care management pasien hipertensi di Pukesmas Kabawetan.

\section{PEMBAHASAN}

Self management adalah prosedur pada individu untuk mengatur prilakunya sendiri. Self management dapat mendorong pasien menggunakan sumber daya yang ada untuk mengelola penyakit yang dialaminya (Lestari \& Isnaini, 2018). Kegiatan dalam self care management hipertensi meliputi penggunaan obat anti hipertensi secara benar, kegiatan untuk memantau tekanan darah dan gejala yang muncul terkait penyakit hipertensi, pengaturan diet yaitu diet yang sesuai untuk penatalaksaanaan hipertensi, melakukan olahraga sesuai petunjuk untuk menurunkan tekanan darah dan kegiatan untuk mencegah komplikasi yang berhubungan dengan hipertensi (Sihotang et al., 2020). Tedapat rbeberapa faktor yang mempengaruhi self management pada penderita hipertensi diantaranya adalah pengetahuan, tingkat pendidikan, dukungan sosial, keyakinan diri (self efikasi) dan lama menderita penyakit hipertensi (Sakinah et al., 2020). Pada penelitian ini didapatkan faktor-faktor yang berhubungan dngan self care management adalah Pengetahuan, Nilai individu, dan Efikasi diri.

Penelitian ini sesuai dengan penelitian Sakinah et al., (2020) didapatkan hasil bahwa terdapat hubungan yang bermakna antara pengetahuan dengan self management hipertensi pada masyarakat suku Timor. Pengetahuan yang baik akan meningkatkan self management hipertensi, begitu pula sebaliknya pengetahuan yang rendah akan berdampak pada rendahnya self management hipertensi pada masyarakat suku Timor. Hasil penelitian ini menunjukan terdapat hubungan yang signifikan antara pengetahuan dengan self care management pasien hipertensi.

Hasil penelitian ini didukung oleh Wei \& Omar (2017) yang menyatakan bahwa pengetahuan, sikap dan persepsi tentang hipertensi memainkan peran yang relatif besar dalam manajemen diri penyakit hipertensi. Pengetahuan akan meningkatkan kesadaran 
(awareness) dalam melakukan kontrol terhadap tekanan darah tinggi, oleh karena itu perlu edukasi untuk meningkatkan pengetahuan dan sikap penderita hipertensi.

Masalah utama manajemen hipertensi adalah sikap klien terhadap penyakitnya yang cenderung tidak patuh dalam melakukan perawatan diri. Hal ini disebabkan karena klien dengan hipertensi memiliki pengetahuan tentang penyakitnya yang rendah dan tidak selalu menerapkan perubahan perilaku yang diinginkan (Romadhon et al., 2020). Sejalan dengan hasil penelitian Gholamnejad et al., (2019) yang menunjukkan bahwa klien hipertensi dengan pendidikan kurang memiliki probabilitas lebih rendah untuk terlibat dalam perilaku perawatan diri pada hipertensi.

Hasil penelitian ini juga sesuai dengan penelitian sebelumnya yang telah menunjukkan bahwa pasien yang mematuhi perawatan mandiri klien Hipertensi sangat erat kaitannya dengan persepsi atau nilai mereka tentang penyakit dan perawatannya (Romadhon et al., 2020). Hasil penelitian ini menunjukan terdapat hubungan yang signifikan antara nilai individu dengan self care management pasien hipertensi.

Hasil penelitian ini juga didukung oleh teori yang mengatakan bahwa persepsi penyakit adalah konsep utama dari pengaturan diri terhadap sehat dan sakit. Berdasarkan konsep tersebut seseorang memiliki kepercayaan pribadi tentang penyakit mereka, yang sebagian besar dapat menentukan respon seseorang terhadap kondisi mereka. Persepsi penyakit meliputi persepsi yang dirasakan yang dikaitkan dengan kondisi seseorang, keyakinan terhadap lama penyakit yang diderita, konsekuensinya, kemampuan yang dirasakan untuk mengendalikan kondisi dan sejauh mana pengobatan efektif dalam mengendalikan kondisi sakitnya, pemahaman tentang kondisinya, respon emosional dan kekhawatiran mengenai kondisinya, dan keyakinan tentang kemungkinan penyebab kondisi tersebut. Persepsi diri dapat memainkan peran penting dalam perilaku manajemen diri penderita hipertensi (Gholamnejad et al., 2019).

Hasil penelitian ini juga sejalan dengan hasil penelitian Puspita et al., (2019) yang mengatakan bahwa efikasi diri penderita hipertensi berhubungan positif dengan perilaku diet hipertensi yang dilakukan sehari-hari. Sehingga, efikasi diri yang baik akan menunjukkan perilaku diet yang baik pula. Selain itu, efikasi diri yang baik menunjukkan perilaku diet hipertensi dua kali lipat lebih tinggi. Dengan demikian meningkatkan kebiasaan perilaku diet yang baik pada penderita hipertensi dapat dilakukan dengan meningkatkan efikasi diri penderita hipertensi tersebut (Puspita et al., 2019). Hasil penelitian ini menunjukan terdapat hubungan yang signifikan antara efikasi diri dengan self care management pasien hipertensi. Hasil penelitian ini didukung oleh penelitian Ismatika \& Soleha (2018) didapatkan hasil bahwa ada hubungan antara self efficacy dengan perilaku self care pasien pasca stroke.

Hasil penelitian ini juga didukung oleh hasil penelitian Sabil et al., (2019) yang menunjukan bahwa faktor yang dapat mempengaruhi pelaksanaan self care management yang tepat adalah health literacy, self efficacy dan dukungan keluarga, namun health literacy dan self efficacy merupakan faktor yang lebih mendominasi untuk mendukung self care management yang tepat. Self efficacy merupakan keyakinan dalam diri seseorang terhadap kemampuan untuk melakukan perilaku demi mendapatkan suatu tujuan tertentu (Octaviyanti, 2020).

Hasil ini menunjukkan bahwa masih terdapat faktor lain yang berhubungan dengan self care management. Seperti pada penelitian Winata et al., (2018) yang melakukan penelitian pada orang dewasa yang mengalami hipertensi di Puskesmas Kendal 01 Kabupaten Kendal. Didapatkan hasil, terdapat hubungan kuat yang positif antara status fungsional dengan self care pasien hipertensi, terdapat hubungan sedang 
yang positif antara dukungan keluarga dengan self care pasien hipertensi. terdapat hubungan yang signifikan antara perubahan emosional dengan self care.

\section{SIMPULAN}

Terdapat hubungan yang signifikan antara pengetahuan dengan self care management pasien hipertensi di Pukesmas Kabawetan, terdapat hubungan yang signifikan antara nilai individu dengan self care management pasien hipertensi di Pukesmas Kabawetan, terdapat hubungan yang signifikan antara efikasi diri dengan self care management pasien hipertensi di Pukesmas Kabawetan.

\section{SARAN}

\section{Bagi Puskesmas}

Diharapkan dapat meningkatkan promosi kesehatan tentang self care managemet hipertensi dengan melakukan penyuluhan.

\section{Bagi Pengembangan Penelitian}

Diharapkan dapat mengembangkan penelitian ini dengan variabel yang berbeda seperti jenis kelamin, pendidikan dan dukungan keluarga.

\section{DAFTAR PUSTAKA}

Andri, J., Padila, P., Sartika, A., Andrianto, M. B., \& J, H. (2021). Changes of Blood Pressure in Hypertension Patients Through Isometric Handgrip Exercise. JOSING: Journal of Nursing and Health, 1(2), 54-64. https://doi.org/10.31539/josing.v1i2.2326

Andri, J., Waluyo, A., Jumaiyah, W., \& Nastashia, D. (2018). Efektivitas Isometric Handgrip Exercise dan Slow Deep Breathing Exercise terhadap Perubahan Tekanan Darah pada Penderita Hipertensi. Jurnal Keperawatan Silampari, 2(1), 371-384. https://doi.org/10.31539/jks.v2i1.382

Fernalia, F., Busjra, B., \& Jumaiyah, W. (2019). Efektivitas Metode Edukasi Audiovisual terhadap Self Management pada Pasien Hipertensi. Jurnal Keperawatan Silampari, 3(1), 221-233. https://doi.org/10.31539/jks.v3i1.770Gholamnejad, H., Darvishpoor-Kakhki, A., Ahmadi, F., \& Rohani, C. (2019). Self-Actualization: Self-Care Outcomes among Elderly Patients with Hypertension. Iranian Journal of Nursing and Midwifery Research, 24(3), 206-212. https://doi.org/10.4103/ijnmr.IJNMR_95_18

Harsismanto, J., Andri, J., Payana, T. D., Andrianto, M. B., \& Sartika, A. (2020). Kualitas Tidur Berhubungan dengan Perubahan Tekanan Darah pada Lansia. Jurnal Kesmas Asclepius, 2(1), 1-11. https://doi.org/10.31539/jka.v2i1.1146

Ismatika, I., \& Soleha, U. (2018). Hubungan Self Efficacy dengan Perilaku Self Care Pasien Pasca Stroke di Rumah Sakit Islam Surabaya. Journal of Health Sciences, 10(2). https://doi.org/10.33086/jhs.v10i2.140

Lestari, I. G., \& Isnaini, N. (2018). Pengaruh Self Management terhadap Tekanan darah. Indonesian Journal for Health Sciences, 2(1), 7-18. https://doi.org/10.24269/ijhs.v2i1.725

Mahfud, M., Barasila, B., \& Indrayani, S. (2019). Dukungan Sosial Berhubungan dengan Self Care Management Pada Lansia Hipertensi di Puskesmas Sedayu II. Dinamika Kesehatan Jurnal Kebidanan dan Keperawatan, 10(2), 700-712. https://doi.org/10.33859/dksm.v10i2.463 
Octaviyanti, D. P. F. (2020). A Literature Review: The Effect of Diabetes Self Management Education on Self- Efficacy in Diabetes Mellitus Patients. Jurnal Genta Kebidanan, 10(1), 38-47. https://doi.org/10.36049/jgk.v10i1.20

Puspita, T., Ernawati, E., \& Rismawan, D. (2019). Hubungan Efikasi Diri dengan Kepatuhan Diet pada Penderita Hipertensi. Jurnal Kesehatan Indra Husada, 7(1), 32. https://doi.org/10.36973/jkih.v7i1.159

Romadhon, W. A., Aridamayanti, B. G., Syanif, A. H., \& Sari, G. M. (2020). FaktorFaktor yang Mempengaruhi Self-care Behavior pada Klien dengan Hipertensi di Komunitas. Jurnal Penelitian Kesehatan "Suara Forikes" (Journal of Health Research "Forikes Voice”), 11, 37. https://doi.org/10.33846/sf11nk206

Sabil, F. A., Kadar, K. S., \& Sjattar, E. L. (2019). Faktor - Faktor Pendukung Self Care Management Diabetes Mellitus Tipe 2: A Literature Review. Jurnal Keperawatan, 10(1), 48. https://doi.org/10.22219/jk.v10i1.6417

Sakinah, S., Ratu, J. M., \& Weraman, P. (2020). Hubungan antara Karakteristik Demografi dan Pengetahuan dengan Self Management Hipertensi Pada Masyarakat Suku Timor. Jurnal Penelitian Kesehatan "SUARA FORIKES" (Journal of Health Research "Forikes Voice"), 11(3), 245. https://doi.org/10.33846/sf11305

Sartika, A., Betrianita, B., Andri, J., Padila, P., \& Nugrah, A. V. (2020). Senam Lansia Menurunkan Tekanan Darah pada Lansia. Journal of Telenursing, 2(1), 11-20. https://doi.org/https://doi.org/10.31539/joting.v2i1.1126

Shahaj, O., Denneny, D., Schwappach, A., Pearce, G., Epiphaniou, E., Parke, H. L., Taylor, S. J. C., \& Pinnock, H. (2019). Supporting Self-Management for People with Hypertension: A Meta-Review of Quantitative and Qualitative Systematic Reviews. Journal of Hypertension, 37(2), 264-279. https://doi.org/10.1097/HJH.0000000000001867

Sihotang, R., Utama, T. A., Aprilatutini, T., \& Yustisia, N. (2020). Self Care Management Evaluation in Hypertension Patients. Jurnal Vokasi Keperawatan (JVK), 3(2), 184-202. https://doi.org/10.33369/jvk.v3i2.13935

Wei, T. M., \& Omar, M. S. (2017). Self-Management Approaches among Hypertensive Residents in Nursing Homes in Malaysia. Malaysian Family Physician, 12(3), 817. https://www.ncbi.nlm.nih.gov/pmc/articles/PMC5842418/pdf/MFP-12-08.pdf

WHO. (2019). Hypertension: Key Facts. https://www.who.int/news-room/factsheets/detail/hypertension

Winata, I. G., Asyrofi, A., \& Nurwijayanti, A. M. (2018). Faktor-Faktor yang Berhubungan dengan Self Care pada Orang Dewasa yang Mengalami Hipertensi di Puskesmas Kendal 01 Kabupaten Kendal. Jurnal Manajemen Asuhan Keperawatan, 2(2), 1-8. https://doi.org/10.33655/mak.v2i2.33 